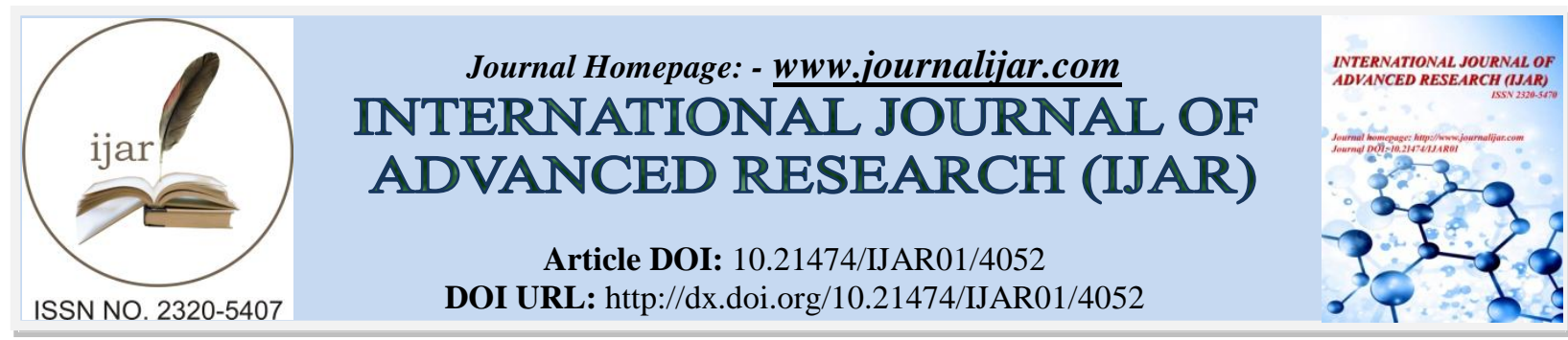

RESEARCH ARTICLE

\title{
RIGHT TO SANITATION: HUMAN RIGHT ASSOCIATED WITH HUMAN DIGNITY
}

\section{Lipika Sharma.}

Research Scholar, Amity Institute of Advance Legal Studies, Amity University, Noida, (Associate Professor of Law) Galgotias University, Greater Noida.

\section{Manuscript Info}

Manuscript History

Received: 26 February 2017

Final Accepted: 28 March 2017

Published: April 2017

Key words:-

Sanitation, human rights Judicial perspective, challenges and gaps

\section{Abstract}

Right to sanitation is basic human right which is directly associated with human decency and dignity. Inadequate sanitation is the root cause of human and environmental degradation. Right to Sanitation basically means availability of facilities for safe disposal of excreta that avoids human, animal and insects contact with hazardous wastes. It entitles everyone without discrimination affordable access to sanitation which is safe hygienic, secure, socially and culturally acceptable and provides dignity. This paper will discuss international documents and commitments related to Sanitation along with Indian Scenario i.e. Constitutional perspective, various laws, rules or regulations dealing with the Sanitation and judicial basis of right to sanitation. Supreme Court of India starting from Municipal council of Ratlam till a judgment on Scavengers have dealt in detail about Sanitation and further in various cases interpreted that right to life includes right to have adequate sanitation. Hence this paper will elaborate on legal instruments incorporating a sanitation dimension, to understand the rationale and approaches of existing legal, policy and institutional frameworks for the realization of the right to Sanitation at National and Local levels. Further implementation challenges, gaps and corrective measures will also be discussed.

Copy Right, IJAR, 2017,. All rights reserved.

\section{"Sanitation is more important than Independence" Mahatma Gandhi}

Sanitation refers to conditions related to public health and maintains hygienic conditions through services such as garbage collection and wastewater disposal. In this paper researchers are trying to define the word 'Sanitation' which is not a word but as a whole, a big idea. The word Sanitation cannot be defined in two three lines but need to develop this as a concept and then include in it all the ramifications of this concept. As when discussing this concept we need to include vary many issues such as collection, storage, and disposal, treatment of excreta, management, reuse, recycle and disposal of solid wastes or rubbish, treatment and disposal of sewage effluents and management of Hazardous wastes. Hence internationally as well as nationally Sanitation needs to be disused as a biggest Health issue which in turn is affecting and will affect in future the development .Along with health issue it is also an environment challenge as well. As when there is no proper disposal and treatment of any kind of waste then it automatically become environment threat. Hence each region, community and country needs to work out that what is the most sensible and cost effective way of thinking about sanitation. Flexibility and pragmatism should be two key words for politicians as well as professionals to discuss the issue of sanitation. The paper will discuss the legal

Corresponding Author:- Lipika Sharma.

Address:- School of Law and Legal Studies, Galgotias University, Greater Noida, Uttar Pradesh, India. 
and policy framework at national and international level dealing with Sanitation. Further implementation challenges, gaps and corrective measures will also be discussed.

\section{International Scenario:-}

Hence to begin with let's discuss what is meant by Sanitation as defined by various treaties, scholars, policy makers and scholars. Although policy commitments made at international summits, forums and conferences (often laid down in declarations) are not legally binding on States, they have a beneficial impact on the further defining and realization of the human rights to water and sanitation, because political commitments undertaken by individual states provide a basis for lobbying in that country and for mobilising community action. They provide a basis for holding governments politically accountable for their action and inaction. The adoption of a number of international policy commitments and declarations on water issues represents global consensus on agreed priorities ${ }^{1}$.

As international events often focus on a certain topic, they lead to an increasing awareness of particular problems individuals and group face with regard to their rights to water and sanitation. Issues for example include the crisis of water resources in cities as a result of rapid urbanisation, gender inequalities and unequal cost burdens born by the poor.

Right to sanitation needs to be discussed with right to water as without water there cannot be any sanitation. Thereafter in the year 1979 the Convention on Elimination of All Forms of Discrimination against Women, was adopted by UN General Assembly. In this convention while discussing rights of women it was specifically stated that state should take measures to eliminate the discrimination against women in rural areas and shall ensure that they enjoy adequate living conditions particularly in relation to housing, sanitation....." ${ }^{2}$. India is signatory to the convention hence committed to implement the same. Agenda 21, UN Conference on Environment and Development calls for provision of safe drinking water, environmental sanitation for poverty alleviation.

Another important Convention with regard to right to sanitation is Convention of Rights of Child. The convention states that signatory states shall take appropriate measures to ensure that all segments of society, in particular parents and children, are informed, have access to education and are supported in the use of basic knowledge of child health and nutrition, the advantages of breastfeeding, hygiene and environmental sanitation and the prevention of accidents ${ }^{3}$. India signed it in 1992 hence committed to implement its provisions and safeguard right of children.

At a regional level, the most explicit recognition of the right to water and the right to sanitation is in the African instruments of the Protection of the Rights of Women and Children. In the Protocol to the African Charter on Human and Peoples Rights regarding the Rights of Women, States made a commitment to ensure access to safe drinking water for women (article 15) and to regulate the management, the processing, the storage and disposal of domestic waste (article 18). In the African Charter of Rights and Wellbeing of the Child, they made a commitment to take all necessary measures to ensure the provision of safe drinking water to children (article 14, paragraph 2$)^{4}$. In the Protocol of San Salvador, which supports the American Convention on Human Rights, States recognized that "Everyone shall have the right to live in a healthy environment and to have access to basic public services" (article 11 , paragraph 1$)^{5}$.

The recognition of and support for the human rights to water and sanitation have developed significantly over recent years. Hence till 2002 internationally right to sanitation was not recognised as individual right but was talked about as part of human right. In 2002 a special committee was appointed by United Nations on economic, cultural and social rights to monitor the implementation of International Covenant on Economic, Social and cultural rights. (ICESCR).The committee talked about the right to sanitation as necessary element of human right to water.

\footnotetext{
${ }^{1}$ http://www.righttowater.info/progress-so-far/

${ }^{2}$ Convention on Elimination of All Forms of Discrimination against Women ,December 18 , 1979, available at http://www.un.org/womenwatch/daw/cedaw/text/econvention.htm

${ }^{3}$ Article 24 (2) (e) Convention on Rights of the Child, 44/25 of $20^{\text {th }}$ November 1989, available at http://www.ohchr.org/en/professionalinterest/pages/crc.aspx

${ }^{4}$ http://base.d-p-h.info/en/fiches/dph/fiche-dph-8111.html

${ }^{5}$ ibid
} 
It was in 1948 that first time sanitation was discussed as part of human right under Universal Declaration of Human Rights in 1948. It is stated that everyone has the right to a standard of living adequate for the health and well-being of himself and of his family ${ }^{6}$.The ICESCR issued in General Comment No. 15 on the right to water in 2002 and the Statement on Sanitation in 2010, explaining the content and meaning of both the right to water and to sanitation.

Some of the international resolutions also discussed right to sanitation along with right to water. Human Rights Council Resolution in September 2010 affirms that the human right to safe drinking water and sanitation is derived from the right to an adequate standard of living and inextricably related to the right to the highest attainable standard of physical and mental health, as well as the right to life and human dignity. The resolution, adopted by consensus by the Human Rights Council and confirmed that the right mentioned therein are legally binding on signatories and it became part of international law.

Thereafter Human Rights Commission in its $16^{\text {th }}$ Session on $8^{\text {th }}$ April 2011, adopted a resolution for 'Human Right to Safe Drinking Water and Sanitation'. September 2013: Resolution A/HRC/RES/24/18 for the first time lists all normative content categories of the rights to water and sanitation. November 2013: Resolution A/RES/68/157 among other things, recalls that the human right to safe drinking water and sanitation is derived from the right to an adequate standard of living and is inextricably related to the right to the highest attainable standard of physical and mental health, as well as to the right to life and human dignity, and reaffirms the recognition of the right to safe drinking water and sanitation as a human right that is essential for the full enjoyment of life and all human rights.

It is important to note that The United Nations Special Rapporteur on the human right to water and sanitation, Léo Heller, and the Chair of the UN Committee on Economic, Social and Cultural Rights, Waleed Sadi, stated that the explicit recognition of the 'human right to sanitation' as a distinct right, together with the 'human right to safe drinking water' by the UN General Assembly is the landmark step.

"The right to sanitation is an essential component of the right to an adequate standard of living, inextricably linked to the highest attainable standard of health, and integrally related to the human right to water," Mr. Sadi said. "The explicit recognition of the human right to sanitation and the human right to water reaffirms that sanitation has distinct features which warrant its own separate recognition and treatment from water in some respects."

\section{Rationale And Approaches:-}

When we talk about the right to Sanitation that same can be dealt with under 3 broad heads or approaches. The main approaches to deal with right to sanitation are Firstly, Rights Based Approach, Secondly ,Needs Based Approach and Lastly Charity Approach.

\section{Rights Based Approach:-}

Right based approach means to treat the right to Sanitation as a Human Right and then make efforts in the direction to achieve the complete implementation to right to sanitation. It is important to note that there a various treaties, conventions and resolutions discussing right to sanitation directly or indirectly and finally making it a legally binding right to be implemented by the member countries, still till date most of the world population lives without adequate sanitation conditions. If we further study the problem then it can be put clearly that those who are deprived of are from the economically weaker sections of the society and marginalized on the bases of caste, religion, ethnic minority, caste, gender and the disadvantageous locations i.e. urban slums, landless poor etc. Hence there is need to focus on process and outcome.

Vulnerability is a structural issue and is caused due to Imbalance in power relations in the society. And these rights based approach deals with causes of discrimination. The approach focuses and addresses underlying issues such as poverty and try to redraw the power relations. Justice is focus of all efforts in this direction. At the bottom of this approach is the thought to make state and other service providers accountable and helpful in implementing rights of marginalized people of the society. Hence right based approaches create possibilities in conflict prevention. Right based approach makes sure that marginalized sections of society participate actively in the developmental process and also deals with causes of discrimination and tries to deal with it effectively. The main focus of right based approach is on realizing rights. Further it tries to empower the needy and help them clam their rights. We can

\footnotetext{
${ }^{6}$ Article 25(1), Universal Declaration of Human Rights, , available at http://www.un.org/en/universal-declarationhuman-rights/
} 
conclude by staying that the focus of this approach is on structural causes and their flaws and impediments in the empowering the people at grass root level. Hence it can be concluded by saying that rights based approach emphasize on giving rights to citizen through legal framework and then help them claim it. This is the rule of law based approach.

\section{Needs Based Approach: -}

Under needs based approach vulnerability is addressed as a symptom of poverty and getting marginalized. This approach basically focuses on input and output. It recognizes needs valid claims and emphasizes on input and does not focus on output. Under this approach individuals are objects of development interventions. Finally it can be stated that this approach focuses on immediate causes of problem. Citizens are considered as beneficiaries of government policies. The aim of this approach is to avoid upheaval and discontent by making arrangements to satisfy the need of people.

\section{Charity Based Approach:-}

The idea behind this approach is recognizing the responsibility of rich towards poor and individuals are seen as victims and they deserve assistance. It basically focuses on manifestation of problems. Finally its focus is on input by government and other power sectors to the society in helping poor and marginalized section of the society to get the right to dignifies life.

\section{Constitutional Basis And Judicial Approach Of Right To Sanitation:-}

Before discussing the article of constitution it is important to mention here that long before getting the independence father of the nation Mahatma Gandhi stated that the availability of sanitation is more important than gaining independence in India. Of late, it is now increasingly felt and realized in India that facilities like toilet, safe drinking water, accompanied by good hygienic conditions are fundamental necessities of a person. These are prerequisites of social and economic justice and genuine development.

There is no specific Article which deals with the Sanitation issue but it finds mention in the directive principles of state policy and judiciary has interpreted right to sanitation as the 'Right to Life' in various judgments. When we talk of Directive Principles of state policy than right to sanitation can be read under Article 38, 39 and 41 .Artcile 38 states that State to secure Social Order for the promotion of welfare of people. Under the said heading social justice is talked about and further it talks about elimination of inequalities in the facilities amongst group of people residing in different areas.

Than Article 39 talks about the responsibility of state to secure for children opportunities and facilities to develop in a healthy manner and in conditions of dignity. Thereafter Article 47 of the Constitution imposes duty on government to raise the level of nutrition and standard of living and to improve public health. Further $11^{\text {th }}$ and $12^{\text {th }}$ Schedules also talks about the government's duty to improve sanitation and health.

Above mentioned are Articles which indirectly deals with right to sanitation. Indian Court while interpreting fundamental rights under Article i.e. Right to Sanitation was read as essential part of right to Life. In Francis Coralie Mullin Vs. The Administrator, Union Territory of Delhi ${ }^{7}$ Supreme Court held that Right to life includes right to live with human dignity. In a case of Bandhua Mukti Morcha V Union of India ${ }^{8}$ a case concerning the living and working conditions of stone quarry workers and whether these conditions deprived them of their right to life. The court held that humane working conditions are essential to the pursuit of the right life. It laid down that workers should be provided with medical facilities, clean drinking water and sanitation facilities so that they may live with human dignity. In another case titled as Citizens and Inhabitants of Municipal Ward v. Municipal Corporation, Gwalior ${ }^{9}$ It was held that the State and its machineries are bound to assure sanitation facilities and maintain hygienic conditions of living. Municipal Council, Ratnam v Shri Vardichan ${ }^{10}$, where the Court had been called upon to decide whether municipalities are obligated to maintain certain conditions to ensure public health. It was held by the court that a public body constituted for the principal statutory duty of ensuring sanitation and health is not entitled to immunity on breach of this duty. Further, "pollutants being discharged by big factories... are a challenge to the

\footnotetext{
${ }^{7} 1981$ (2) SCR 516

${ }^{8}$ A.I.R. 1984 S.C. 802,808

${ }^{9}$ AIR 1997 MP 33, 1996

${ }^{10} 1980$ (4) SCC 162
} 
social justice component of the rule of law". M. C Mehta v. Kamal Nath ${ }^{11}$ Supreme Court made it crystal clear that any disturbance of basic environmental elements namely air, water and soil which are necessary for life would be hazardous to life and can't be polluted. (Hotel was discharging effluent into river and hence causing disturbance to aquatic life and water sanitation). T.K. Koolwal v. State of Rajasthan

The High court extended the right to know to entitle a person to have complete information about the sanitation Programme of the municipal corporation. Hence, the citizens' access to official environmental information within reasonable limits is now a guaranteed right. ${ }^{12}$

\section{Policy Framework To Deal With Right To Sanitation}

India has been working hard to improve sanitation conditions and is able to improve the same at various levels. Since 1980's India has made efforts to implement its commitments to various resolutions, conventions and treaties etc. India though a fastest growing economy is still lagging behind in providing basic sanitation facilities to its citizens. But it is appreciable how India is making efforts to deal with the problem and the issue is dealt with from various angles.

India has made it part of its five year planning, Central rural sanitation program, Total Sanitation program, Nirmal Bharat Abhiyan, Nirmal Gram Puraskar, The Nirmal Shahar Puraskar, Jawaharlal Nehru National Urban Renewal Mission, National Urban Sanitation Policy etc. these are few to mention concrete steps taken by India to improve sanitation conditions. Important step in direction was also prohibited "manual scavenging". A specific Indian problem "manual scavenging" which is connected to caste system, and relates to unsafe and undignified emptying of toilets and pits, as well as handling of raw, untreated human excreta.

In 2001, the Government of India launched a national community sanitation Programme called Nirmal Bharat Abhiyan in slums across the country. Due to high slum density, community toilets were proposed as a sustainable and cost-effective option as compared to individual or family latrines. The Programme emphasized community involvement in the design, construction and maintenance of facilities rather than leaving it to municipal authorities ${ }^{13}$.

The project helped raise the profile of sanitation in India to the highest level. In 2006, India's Ministry of Urban Development (MoUD) formed a national task force on urban sanitation, comprising representatives from the central, state and city governments as well as NGOs and relevant city institutions.

In 2009, based on the task force's recommendations, the national government announced a National Urban Sanitation Policy (NUSP) - India's first comprehensive urban sanitation policy that promises universal access with a special focus on people living in underserved areas. The Policy provides a framework for all Indian States to approach urban sanitation in an integrated manner. It is now mandatory for the central government to support states and cities in developing their own sanitation strategies and plans. An Advisory Group reviews policy implementation and progress at all levels National Urban Sanitation Policy.

The Policy takes a holistic approach to sanitation and is integrated with other urban projects as part of the government's overall poverty alleviation agenda. To illustrate, the Ministry of Housing and Poverty Alleviation has developed a national strategy which emphasizes sanitation services to the poor as part of its overall mission to provide basic services to the poor.

The Policy's emphasis on a community-driven approach to sanitation provision is another visible departure from the government's previous top-down approach to service delivery. The NUSP recognizes that building toilets is not the solution to the challenges of providing sanitation in slums if local communities are not actively involved ${ }^{14}$.

India's Response to the Sanitation Crisis and India initially tended to the requirement for enhanced sanitation in 1980.Although it's not enough reacting at to begin with; ${ }^{15}$ India soon demonstrated its dedication through actualizing a few projects throughout the years.

\footnotetext{
${ }^{11}$ [2000]Supp1SCR389.

${ }^{12}$ AIR 1988 Raj. 2

${ }^{13} \mathrm{http}: / /$ www.citiesalliance.org/node/3416

${ }^{14} \mathrm{http}: / / \mathrm{www} . c i t i e s a l l i a n c e . o r g /$ node/3416
} 
Through these projects, sanitation has enhanced drastically, however there are still a substantial number of individuals living without access to sufficient sanitation.

In quest for the major rights ensured in the Constitution of India, the administration built up the Planning Commission in March of $1950^{16}$.

The part of the Planning Commission incorporates surveying the country's assets, figuring an arrangement that most adequately uses those assets, distinguishing variables obstructing financial development, assessing the advance of the set up plans, and making recommendations ${ }^{17}$.

Since 1951, the Planning Commission has set up an arrangement at regular intervals. ${ }^{18}$ The Planning Commission initially tended to the sanitation emergency in the Sixth Five Year Plan started in 1980. By the Seventh Five Year arrange, the Planning Commission set an objective to "give $25 \%$ of country families with individual family sterile toilets.

Currently, India is nearing the end of its Eleventh Five Year Plan with the Twelfth Five Year Arrange effectively in progress. ${ }^{19}$ The Eleventh Five Year Plan addresses the insufficiencies of sanitation in rustic regions and asserts the nation's dedication to the Total Sanitation Campaign which calls for finish sanitation scope by the year 2012 .

The Constitutional and authoritative system of the water rights administration exhibits an intricate picture of division of forces and obligations as respects to water assets in India. The State government has the ability to make laws in regard of water assets existing in that state subject to conditions and restrictions set around Parliament every once in a while.

The established power is offered to the State governments by temperance of section 17 of the State List6, passage 56 in the Union List furthermore one must not overlook Article 262 of the Constitution ${ }^{20}$. The plain perusing of Article 262 of the Indian Constitution gives that Parliament may by law accommodate the settling of any question or grumbling as for the utilization, conveyance or control of the waters of, or in, any Inter-State stream or waterway valley. $^{21}$

Advance, Sub-Clause (2) of Article 262 additionally expresses that despite anything in this Constitution, Parliament may by law give that neither the Supreme Court nor some other court might practice locale in regard of any such question or protestation as is alluded to in condition (1). Along these lines, even the pinnacle court's ward has been removed in the matters of water. This highlights the significance of water rights furthermore the fears of the legislature in managing clashes

The Central Rural Sanitation Program (CRSP) was the primary across the nation program to react to the sanitation predicament of India. ${ }^{22}$ The legislature propelled the program in 1986 to "[improve] the personal satisfaction of country individuals and [provide] security and poise to ladies. The legislature monetarily supported the CRSP which

15 http://www.economywatch.com/five-year-plans/.

${ }^{16}$ Water aid, Feeling The Pulse: A Study Of The Total Sanitation Campaign In Five States 2 (2008), available at http://www.wsscc.org/sites/default/files/india-wateraid-feeling-the-pulse-totalsanitationsCampaign_2008.pdf

${ }^{17} \mathrm{http}: / /$ www.wakeupcall.org/administration-inindiafpoverty-line.php\# (

${ }^{18} \mathrm{http}: / / w w w . u n i c e f o r g / i n d i a / r e a l l i v e s \_5112 . h t m$

19 Approach to the twelfth five year plan, govt's of India plan. Commission, available at http://planning commission.gov.in/plans/comments/inter.htm

${ }^{20}$ Iyer Ramaswamy R, ,, Water \& The Laws in Indiace, sage Publications Pvt Ltd , 2009

${ }^{21}$ Sekhar Bonu \& Hun Kim, Sanitation in India: Progress, Differentials, Correlates, and Challenges3 (Asian Dev. Bank, South Asia Occasional Paper Series No. 2, 2009), available at http:llwww.indiaenvironmentportal.org.in/files/sanitation.pdf.

${ }^{22}$ Govt of India planning comm'n, eleventh five year plan: agriculture, rural Development, industry, services and physical infrastructure (2008), 
concentrated on the development of individual toilets for family units beneath destitution line, ${ }^{23}$ procuring fewer than 3650 rupees, or 75 US dollars, every year.

Other parts of the Central Rural Sanitation Program (CRSP) included "transformation of dry lavatories to water-pour flush toilets, development of town clean buildings for ladies, setting up sterile bazaars and generation focuses" to give materials to building offices, and making mindfulness and wellbeing training .The CRSP given huge sponsorships to development of sanitation offices in the group also, in individual households." The administration saw the arrangement of sanitation materials and administrations as an obligation of the states and Gram Panchayats, "the most minimal level of chose provincial neighborhood government." 24

\section{Efforts In India To Improve Sanitation:-}

As we know various inventive ways to deal with enhance water supply and sanitation have been tried in India, specifically in the mid 2000s. These incorporate request driven methodologies in provincial water supply since 1999, group drove add up to sanitation, public-private organizations to enhance the congruity of urban water supply, and the utilization of microcredit to ladies keeping in mind the end goal to enhance access to water ${ }^{25}$

India add up to sanitation crusade gives solid accentuation on Information, Education, and Communication, limit building and cleanliness instruction for compelling conduct change with contribution of panchayati raj foundations, people group based associations and non-governmental associations, and so on ${ }^{26}$.

The key mediation ranges are singular family unit lavatories, school sanitation and cleanliness training, people group sterile complex, Anganwadi toilets upheld by Rural Sanitary Marts, and generation focuses ${ }^{27}$. The primary objective of the legislature of India is to annihilate the act of open crap by 2010.

To offer fillip to this attempt, Government of India has propelled Nirmal Gram Puraskar to perceive the endeavors regarding money grants for completely secured panchayati raj institutions and those people and foundations who have contributed fundamentally in guaranteeing full sanitation scope in their general vicinity of operation. The venture is being actualized in rustic ranges taking area as a unit of execution ${ }^{28}$.

Most of the intercessions (counting different hygiene, cleanliness, and water quality) were found to fundamentally lessen the levels of diarrheal disease, with the best effect being seen for cleanliness and family treatment interventions.

Interventions to enhance water quality at the family level are more successful than those at the source. Unfortunately, in creating nations, general wellbeing concerns are normally raised on the institutional setting ${ }^{29}$. For example, civil administrations, doctor's facilities, and ecological sanitation. There is a hesitance to recognize the home as a setting of equivalent significance alongside the general population organizations in the chain of transmission in the group. ${ }^{30}$ Administrators of home cleanliness and group cleanliness must act as one to upgrade come back from endeavors to advance general wellbeing.

The part of the WHO Guidelines for Drinking Water Quality underscores a coordinated way to deal with water quality evaluation and administration from source to customer.

\footnotetext{
${ }^{23} \mathrm{http}: / /$ esa.un.org

${ }^{24} \mathrm{http}: / /$ www.tearfund.org/webdocs/website/campaigning/policy\%20and\%20research/sanitation\%20scandalMadagas carSan-web.pdf.

${ }^{25} \mathrm{http} / / /$ www.gtz.de/en/dokumente/en-ecosan-sustainablesanitation-india-2008.pdf .

${ }^{26}$ :http://www.ddws.nic.in/tsc_index.htm

${ }^{27}$ Pandve HT. Environmental sanitation: An ignored issue in India. Indian J Occup Environ Med. 2008

${ }^{28}$ Bhatt MR. Women in water management: the need for local planning. Dev Pract.1995;5:254-8

${ }^{29} \mathrm{http}: / / \mathrm{www}$. searo.who.int/LinkFiles/SDE_trends-ind.pdf

${ }^{30}$ Fewtrell L, Colford JM., Jr Water, sanitation and hygiene in developing countries: interventions and diarrhoea--a review. Water Sci Technol. 2005.
} 
${ }^{31}$ It stresses on quality insurance and avoidance of tainting and encourages being proactive and participatory, and addressing the necessities of those in creating nations who have no entrance to channeled group water supplies.

The rules underscore the support of microbial quality to avoid waterborne irresistible malady as a crucial objective. What's more, they address security from synthetic toxicants and different contaminants of general wellbeing concern $^{32}$.

${ }^{33}$ There are a few explanations behind a national approach perceiving sanitation as a human right. First, acknowledgment will guarantee that entrance to sanitation is a "lawful qualification, as opposed to philanthropy or just an ethical priority."

${ }^{34} \mathrm{~A}$ lawful privilege gives the fundamental establishment to holding the legislature and other mindful performing artists responsible for elevating access to sanitation. Second, perceiving a privilege to sanitation will make an emphasis on defenseless and minimized gatherings who have been overlooked or segregated against before if sanitation for all is an order, groups will be constrained to occupy center from upper-and center wage gatherings to the individuals who require sanitation the most.

Third, recognizing sanitation as a right will increment data sharing and investment in basic leadership. ${ }^{35}$ The privilege to water what's more, sanitation can enable and empower groups to sort out themselves, look for and acquire data, and authentically participate in and impact the results of pertinent basic leadership forms to put it plainly, perceiving a privilege to sanitation can serve as a lawful and political apparatus to be utilized.

\section{Implementation Challenges, Gaps And Corrective Measures:- Implementation:-}

In India more than 620 million individuals crap in the open; this speaks to a large portion of the populace. The other half have gotten to be ignorant concerning the practice - it is a socially acknowledged standard ${ }^{36}$.

A change is desperately required. Everybody needs to consider the act of open crap as absolutely inadmissible. Human excreta in the earth speak to a hazard to every one of us, and, subsequently, we have an obligation to raise our voice, see our obligation as natives contrastingly and bolster endeavors to end this practice. ${ }^{37}$ The most ideal approach to begin is to get the message out this is not worthy in the India we as a whole need to live in" .Every year about 20 million individuals are beginning to utilize a toilet- ending the between generational propensity that was educated to them as babies.

However, 20 million new clients a year is insufficient to guarantee that all kids are naturally introduced to a situation that won't add to them being hindered; where they will no longer experience the ill effects of rehashed scenes of loose bowels; and where young ladies will be free from badgering and shame as they enter adolescence ${ }^{38}$.

People with inabilities, ladies, young ladies and socially prohibited groups are the most exceedingly terrible sufferers of this disregard as well. All the more particularly, the legislature of India information indicates genuine services with gigantic number of toilets not existing on the ground as well as monstrous holes between what has been provisioned and real numbers.

31 Sobsey MD, Bartram S. Water quality and health in the new millennium: the role of the World Health Organization Guidelines for Drinking-Water Quality. Forum Nutr.2003

$32 \mathrm{http}$ //southasia.oneworld.net/todaysheadlines/inadequate-sanitationcosts-india-54-billion-yearly .

${ }^{33}$ Nath KJ. Home hygiene and environmental sanitation: a country situation analysis for India. Int J Environ Health Res. 2003

${ }^{34}$ Bhatt MR. Women in water management: the need for local planning. Dev Pract.1995

35 Davis J, White G, Damodaron S, Thorsten R. Improving access to water supply and sanitation in urban India: microfinance for water and sanitation infrastructure development. Water Sci Technol. 2008.

${ }^{36} \mathrm{http}: / /$ www.ohchr.org/EN/newsevents/Pages/righttosanitation.aspx.

${ }^{37} \mathrm{http}: / / \mathrm{www}$.righttowater.info/right-to-sanitation/

${ }^{38} \mathrm{http}$ ://www.thehindu.com/opinion/editorial/the-right-to-sanitation/article4853820.ece. 
${ }^{39}$ This issue of 'missing toilets' in country India emergency's in urban ranges require quick consideration of every last one. Also, in Delhi, the circumstance is troubling with a huge populace still does not have entry to safe sanitation without access to utilitarian toilets, insufficient ooze administration framework and seepage.

Government imitative many direction for implanting the right to sanitation in the society .like in a way Guarantee Universal Access to Sanitation incorporating into all families, schools, wellbeing focuses, work places, open structures and open spaces/places ${ }^{40}$.

${ }^{41}$ Guarantee access to sanitation in all circumstances including debacles, crises, clashes and relocation. Guarantee access to sanitation administrations to make them usable and available for the whole populace, with a unique accentuation on poor and minimized ranges and aggregates, and create isolate sanitation speculation arrangements to connect these administration crevices in both rustic and urban zones including ghettos.

Create participatory multi-partner observing instrument for yearly reporting against clear signs for poor, minimized and prohibited gatherings, incorporating individuals with handicaps, ladies, kids and more established individuals.

\section{Challenges Of Implementing And Required Corrective Measures:-}

The general wellbeing challenge natural is guaranteeing that upgrades result in access to water and sanitation for the basic at-hazard populaces. Inventive methodologies are required to guarantee the accessibility of minimal effort, straightforward, and locally satisfactory water and sanitation intercessions and incorporating these methodologies into existing social foundations, for example, schools, markets, and wellbeing offices

Prevention of pollution of water in dissemination frameworks, Growing water shortage and the potential for water reuse and preservation, Implementing creative minimal effort sanitation framework Providing manageable water supplies and sanitation for urban and semi urban ranges Reducing aberrations inside the locales in the nation Sustainability of water and sanitation administrations.

Guarantee access to sanitation administrations to make them usable and open for the whole populace, ${ }^{42}$ with an extraordinary accentuation on poor and minimized regions and gathers, and create isolate sanitation venture arrangements to connect these administration crevices in both provincial and urban regions including ghettos.

All the more particularly, the legislature of India information demonstrates genuine crevices with immense number of toilets not existing on the ground as well as gigantic holes between what has been provisioned and real numbers.

The action needs, drinking water supply, maintainability measures, empowering target groups to end up defecation free, environmental sanitation, health education, income generating activities, and so on. ${ }^{43}$ Endorsement of State Finance and Planning Departments ought to be gotten to guarantee that the proposition has been investigated for its reasonability.

The advance ought to be observed at the level of Secretary in the State to guarantee the finish of undertakings on time to stay away from cost invades and to take fitting healing measures.

As we know various inventive ways to deal with enhance water supply and sanitation have been tried in India, specifically in the mid 2000s. These incorporate request driven methodologies in provincial water supply since 1999, group drove add up to sanitation, public-private organizations to enhance the congruity of urban water supply, and the utilization of microcredit to ladies keeping in mind the end goal to enhance access to water ${ }^{44}$

\footnotetext{
39 ibid

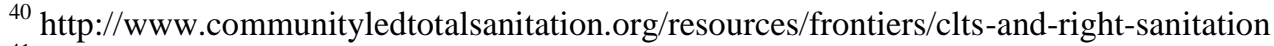

${ }^{41} \mathrm{http}: / /$ cafindia.org/pages/why-rts.htm

$42 \mathrm{http}: / /$ samarthyam.com/r2s-right-to-sanitation.

${ }^{43} \mathrm{http}: / / \mathrm{www} . \mathrm{mdws} . \mathrm{gov} . \mathrm{in} /$ support-activities

${ }^{44}$ http://www.gtz.de/en/dokumente/en-ecosan-sustainablesanitation-india-2008.pdf .
} 
India add up to sanitation crusade gives solid accentuation on Information, Education, and Communication, limit building and cleanliness instruction for compelling conduct change with contribution of panchayati raj foundations, people group based associations and non-governmental associations, and so on ${ }^{45}$.

The key mediation ranges are singular family unit lavatories, school sanitation and cleanliness training, people group sterile complex, Anganwadi toilets upheld by Rural Sanitary Marts, and generation focuses ${ }^{46}$. The primary objective of the legislature of India is to annihilate the act of open crap by 2010.

To offer fillip to this attempt, Government of India has propelled Nirmal Gram Puraskar to perceive the endeavors regarding money grants for completely secured panchayati raj institutions and those people and foundations who have contributed fundamentally in guaranteeing full sanitation scope in their general vicinity of operation. The venture is being actualized in rustic ranges taking area as a unit of execution ${ }^{47}$.

A late study highlighted that arrangement move to incorporate better family water quality administration to supplement the proceeding with extension of scope and updating of administrations would give off an impression of being a financially wellbeing mediation in numerous creating countries ${ }^{48}$.

Most of the intercessions (counting different hygiene, cleanliness, and water quality) were found to fundamentally lessen the levels of diarrheal disease, with the best effect being seen for cleanliness and family treatment interventions.

Interventions to enhance water quality at the family level are more successful than those at the source. Unfortunately, in creating nations, general wellbeing concerns are normally raised on the institutional setting ${ }^{49}$. For example, civil administrations, doctor's facilities, and ecological sanitation. There is a hesitance to recognize the home as a setting of equivalent significance alongside the general population organizations in the chain of transmission in the group. ${ }^{50}$ Administrators of home cleanliness and group cleanliness must act as one to upgrade come back from endeavors to advance general wellbeing.

The part of the WHO Guidelines for Drinking Water Quality underscores a coordinated way to deal with water quality evaluation and administration from source to customer.

${ }^{51}$ It stresses on quality insurance and avoidance of tainting and encourages being proactive and participatory, and addressing the necessities of those in creating nations who have no entrance to channeled group water supplies.

The rules underscore the support of microbial quality to avoid waterborne irresistible malady as a crucial objective. What's more, they address security from synthetic toxicants and different contaminants of general wellbeing concern $^{52}$.

The initial phase in enhancing sanitation scope the U.N. Sub- Commission Guidelines even noticed that "states ought to at all levels of government formally perceive the privilege to water and sanitation in important laws and regulations.

\footnotetext{
45 :http://www.ddws.nic.in/tsc_index.htm

${ }^{46}$ Pandve HT. Environmental sanitation: An ignored issue in India. Indian J Occup Environ Med. 2008

${ }^{47}$ Bhatt MR. Women in water management: the need for local planning. Dev Pract.1995;5:254-8

${ }^{48}$ Nath KJ. Home hygiene and environmental sanitation: a country situation analysis for India. Int J Environ Health Res.

${ }^{49}$ http://www.searo.who.int/LinkFiles/SDE_trends-ind.pdf

${ }^{50}$ Fewtrell L, Colford JM., Jr Water, sanitation and hygiene in developing countries: interventions and diarrhoea--a review. Water Sci Technol. 2005.

51 Sobsey MD, Bartram S. Water quality and health in the new millennium: the role of the World Health Organization Guidelines for Drinking-Water Quality. Forum Nutr.2003

${ }^{52} \mathrm{http}: / /$ southasia.oneworld.net/todaysheadlines/inadequate-sanitationcosts-india-54-billion-yearly
} 
${ }^{53}$ There are a few explanations behind a national approach perceiving sanitation as a human right. First, acknowledgment will guarantee that entrance to sanitation is a "lawful qualification, as opposed to philanthropy or just an ethical priority."

${ }^{54} \mathrm{~A}$ lawful privilege gives the fundamental establishment to holding the legislature and other mindful performing artists responsible for elevating access to sanitation. Second, perceiving a privilege to sanitation will make an emphasis on defenseless and minimized gatherings who have been overlooked or segregated against before if sanitation for all is an order, groups will be constrained to occupy center from upper-and center wage gatherings to the individuals who require sanitation the most.

Third, recognizing sanitation as a right will increment data sharing and investment in basic leadership. ${ }^{55}$ The privilege to water what's more, sanitation can enable and empower groups to sort out themselves, look for and acquire data, and authentically participate in and impact the results of pertinent basic leadership forms to put it plainly, perceiving a privilege to sanitation can serve as a lawful and political apparatus to be utilized.

\section{Conclusion:-}

The right to sanitation campaign in India is at base of Indian state's international commitment . to the enactment of such a right. India is doing great by increasing allocation of funds to establishing sanitation facilities in the country. However, there is a need to ensure that these efforts are not limited to an open-defecation-free focus, and that a holistic understanding of the right to sanitation undergirds these efforts. It is not only the dignity of individuals that is at stake, but also the dignity of a country that aspires to play a significant role in the 21 st century. As Gandhi said, there is more need for toilets than temples in our country. The right to sanitation therefore calls on all Indians to work with it towards establishing this crucial right for all those who live within our geographical borders. Access to adequate sanitation is obviously closely related to human dignity.

"No innovation in the past 200 years has done more to save lives and improve health than the sanitation revolution triggered by invention of the toilet. But it did not go far enough. It only reached one-third of the world."

Sylvia Mathews Burwell

\footnotetext{
${ }^{53}$ Nath KJ. Home hygiene and environmental sanitation: a country situation analysis for India. Int J Environ Health Res. 2003

${ }_{55}^{54}$ Bhatt MR. Women in water management: the need for local planning. Dev Pract.1995

${ }^{55}$ Davis J, White G, Damodaron S, Thorsten R. Improving access to water supply and sanitation in urban India: microfinance for water and sanitation infrastructure development. Water Sci Technol. 2008.
} 